\title{
Vapaa sivistystyö sosiaalisen pääoman rakentajana
}

\author{
$+y$ \\ Vapaan sivistystyön on kyettävä perustelemaan paikkansa ja hyötynsä \\ yhteiskunnassa. Kuinka aineetonta hyötyä, kuten sosiaalista \\ pääomaa, tulisi mitata?
}

RIKAS ON SE yhteiskunta, jolla on varaa menettää osa kansalaisistaan koulun keskeyttämisen, työelämästä syrjäytymisen, työttömyyden, masentumisen, laitostamisen, perhetraumojen tai muun sellaisen seurauksena. Kaikki nämä ovat asioita, jotka kannattaisi hoitaa ajallaan ja säästää tulevaisuudesta. Ongelmien ratkaisua on helppo lykätä tai ratkaista ne väärin, jolloin kustannukset ovat monenkertaisia. Tuskin kenenkään 1990-luvun alkupuolella päätöksiä tehneen poliitikon, pankinjohtajan ja työelämän vaikuttajan tarkoitus oli jättää jälkeensä toiseen ja jopa kolmanteen sukupolveen periytyvää köyhyyttä, työttömyyttä tai jatkuvasti eriarvoistuvaa kansalaisyhteiskuntaa. Niin kuitenkin tapahtui.

Vuosikymmenien ajan vaivalla rakennettu hyvinvointi, yhteiskunnallinen luottamus ja sosiaalinen turvaverkko purettiin pikavauhtia etenkin heikoimmilta. Ongelmat ratkottiin "sokkihoitotoimenpitein", monetarismin ja managerialisen uuden julkishallinnon keinoin. Syntyi kvartaalikapitalismi ja markkinalähtöinen uusi julkishallinto (New Public Management, NPM) sekä niiden yhdistelmänä globaali finanssitalous, jossa suurten voittojen saalistus kohdistuu, ei vain yksittäisiin markkinatoimijoihin vaan kokonaisiin valtioihin. Jopa Euroopan unioni on ajettu tilanteeseen, jossa sen politiikan liikkumavara on käytetty ja todellinen valta näyttää olevan harvojen maailmanlaajuisten finanssikorporaatioiden käsissä.

Julkista taloutta on kurjistettu hyvätuloisten ja rikkaiden verotusta keventämällä, otettu tilalle velkaa ja vaadittu säästöjä hyvinvoinnin kustannuksella. Talouseliittien ahneus ja sitä seurannut moraalikato näyttää leviävän syövän lailla kaikkiin niihin, joilla on pienikin tilaisuus hyötyä rahallisesti jonkun muun kustannuksella. Yhteiskunta on menettämässä hyvää vauhtia ihmisten keskinäisen luottamuksen ja sen mukana sosiaalisen pääoman, joka ilmeni so- 
tien jälkeisen jälleenrakennuskauden "konsensusSuomen”aineellisena ja henkisenä hyvinvointina.

Hyvinvoinnin rahoittamisen kriisi koskee myös vapaata sivistystyötä. Rahan puute on helppo ymmärtää, mutta miten kriisiin johtaneet syyt liittyvät vapaaseen sivistystyöhön? Mitä tekemistä sosiaalisen pääoman kasaamisella tai murenemisella on vapaan sivistystyön kanssa?

\section{SOSIAALINEN PÄÄOMA JA VAPAA SIVISTYSTYÖ}

Aikaisemmin vapaan sivistystyön asema on ollut niin vakaa, että sivistymistä, opintojen, kulttuurin ja kädentaitojen harrastamista pidettiin itsestään selvyytenä samoin kuin sitä, että valtio ja kunnat sen rahoittavat. Nyt vapaan sivistystyön on kyettävä perustelemaan paitsi yksilöille myös koko yhteiskunnalle siitä koituva hyötynsä. Siihen tarvitaan todisteita, mittareita ja indikaattoreita, joilla vapaan sivistystyön tuottama sivistyshyöty voidaan osoittaa.

Esimerkiksi terveydenhoito on kokonaisvaltainen järjestelmä, joka tuottaa terveyshyötyä ${ }^{1}$ sairauksia ehkäisevänä ja kaikkia kansalaisia hyödyttävänä järjestelmänä. Eurooppalaisten raja-aitojen poistuessa kyse ei enää ole vain kansallisesta järjestelmästä. Taloudellinen yhteisyys muuttuu vähitellen myös sosiaaliseksi yhteisyydeksi. Vastaavasti konfliktien, ristiriitojen ja riitatapausten ehkäisy sovittelevan oikeuden muodossa tuottaa oikeushyötyä², mikä tarkoittaa yksilöille koituvaa psyykkistä ja sosiaalista hyötyä, tarvittaessa myös aineellista hyvitystä, mutta ennen kaikkea merkittäviä säästöjä yhteiskunnalle, kun oikeudenkäyntikulut jäävät toteutumatta. Sovittelu on prosessi, joka perustuu luottamuksen rakentamiseen ja dialogiin. Prosessi tuottaa osallisille välitöntä oppimista ja pidemmällä aikavälillä yhteistä sosiaalista pääomaa, jonka perusta on kansalaisten välinen luottamus.

Kokonaisvaltainen, konkreettinen sivistyshyöty ja sosiaalisen pääoman rakentaminen vapaan sivistystyön perusteluna ei ole uusi. Voidaan väittää, että juuri sivistyshyöty, lyhyen ja pitkän aikavälin vaikutuksin, on ollut ensin kansanopetuksen ja sitten vapaan kansanvalistustyön, myöhemmin vapaan sivistystyön tärkein syntytekijä. Vaikka sivistyksellä on itseisarvonsakin, sillä ei olisi riittävää käyttövoimaa kansan- liikkeiden synnyttämiseksi ja valtion perustamiseksi. Sen sijaan kulttuurisen olemassaolon ja yhteiskunnallisen hyvinvoinnin sekä yksilöiden toimeentulon ja hyvän elämän tavoittelu sivistystyön lähtökohtana voivat sitä olla.

Jokisen, Poikelan ja Sihvosen (2012) pamfletinomainen tutkimusraportti Sivistyshyöty ja sosiaalinen pääoma vapaassa sivistystyössä tarkastelee vapaan sivistystyön tehtävää ja hyötyä sosiaalisen pääoman luomisen näkökulmasta. Raportin mukaan mitään suurta itseisarvoista sivistyspoliittista agendaa ei ole ollut, kuten ei ole itseisarvoista sivistystyötäkään. Sen sijaan sivistystyön hyöty on verrattavissa terveys- tai oikeushyötyyn. Hyödyt on kyettävä myös osoittamaan, mikä ei ole aivan helppoa. Kokonaisvaltaisten vaikutustensa takia sivistymisestä koituvia hyötyjä on hankala mitata. Juhlapuheet ja retoriikka voidaan hetkeksi panna sivuun ja kysyä, miten vapaa sivistystyö on luonut ja yhä voi luoda uutta sosiaalista pääomaa?

\section{Uusintava ja uudistava sosiaalinen pääoma}

Sosiaalinen pääoma vertautuu Ruuskasen (2001) mukaan muihin aineetonta pääomaa tarkoittaviin käsitteisiin, kuten inhimillinen, kulttuurinen ja intellektuaalinen pääoma. Käsitteellä tarkoitetaan sosiaalisen rakenteen aineettomia ominaisuuksia, jotka liittyvät ihmisten välisiin verkostoihin, normeihin ja luottamukseen, jotka puolestaan edistävät vuorovaikutusta, tavoitteita ja toimintaa. Sana pääoma viittaa taloudelliseen toimintaan, jossa sosiaalisilla resursseilla, taidoilla ja asemalla on merkitystä. Sosiaalisen pääoman tutkimuksen kohteeksi ovat nousseet erityisesti yksilöiden sosiaaliset, avoimet ja suljetut suhdeverkostot, luottamuksen, rationaalisen valinnan ja optimoinnin ongelmat, niin sanotut heikot siteet sekä yksityis- ja julkishyödykkeen käsitteet (esim. Coleman 1988). Sosiaalinen pääoma on hyödyke, johon sisältyy ristiriitaisia intressejä. Se on myös haitake, koska ryhmäspesifinä sitä voidaan käyttää toista ryhmää vastaan.

Sosiaalisen pääoman tuotoksia ovat kulutushyödyt, jotka tarkoittavat luottamuksen ja kommunikaation tuottamaa välitöntä mielihyvää sekä pääomahyödyt, jotka liittyvät yhteistoiminnan helpottumiseen, 
toimintojen koordinointiin, liiketoimintakustannusten alenemiseen ja sosiaaliseen tukeen. Sosiaalisen pääoman oletetaan kasautuvan fyysisen pääoman tapaan. Verkostoteorian mukaan se kasautuu ihmisten suhdeverkon optimoinnin ja verkostokeskeisen aseman hankkimisen tuloksena. Taloussosiologisen lähestymistavan mukaan kasautuminen tapahtuu verkoston ja sen normien sekä yhteisen identiteetin ja tietoisuuden rakentamisen tuloksena. Organisaatioteoriassa puhutaan osaamispääomasta, jonka kasautuminen riippuu yrityksen tietojohtamisesta, prosessien, innovaatioiden ja aineettomien hyödykkeiden hallinnasta. (Ruuskanen 2001.)

Bourdieun (1986) mukaan yksilöt sijoittuvat yhteiskunnan erilaisille sosiaalisille valtakentille kilpailun tuloksena. Erityisen merkittävää kilpailussa on taloudellinen, kulttuurinen ja sosiaalinen pääoma, joka tarkoittaa tuttavuus- ja arvostussuhteita ja niin sanotun symbolisen pääoman hallintaa. Asema heijastuu haltijansa "habitukseen", symboleihin ja tapoihin kiinnittyneen käyttäytymisen kautta. Sosiaaliset suhteet ovat "klubihyödyke", joka ilmentää kuulumista tiettyyn ryhmään ja asemaan sosiaalisissa kerrostumissa.

Sosiaalinen pääoma on kasvuteorian mukaan inhimillistä pääomaa, joka kasautuu koulutuksen ja kokemuksen kautta oppimisen tuloksena. Institutionaalisen teoriasuuntauksen mukaan sosiaalinen pääoma kasautuu kansalaiskasvatuksen, paikallisen sosiaalisen vuorovaikutuksen ja yhteisöllisyyden edistämisen kautta. Oppiminen, kasvatus ja koulutus ovat sosiaalisen pääoman kasaamisen keinoja, eivät niinkään uuden sosiaalisen pääoman luomisen välineitä. (Ruuskanen 2001.) Mutta kun oppimista koskeva kysymyksenasettelu laajennetaan tiedon prosessointiin ja innovaatioihin, saadaan esiin sosiaalisen luovuuden, innovaation aspekti.

Tuomi (2004) väittää, että kaikki pääoma on sosiaalista, koska pääomalla on käyttöä sosiaalisessa vaihdossa sosiaalisen järjestelmän ehdoin. "Sosiaalista pääomaa voidaan pitää pääoman erikoistapauksena vain silloin, kun yhteiskunnan järjestys oletetaan niin vakiintuneeksi, ettei siitä tarvitse puhua. Myös kaikki innovaatiot ovat sosiaalisia innovaatioita. Innovaation sosiaalinen luonne eroaa pääoman sosiaalisesta luonteesta siinä, että innovaatio muuttaa yhteiskunnan järjestystä. Pääoma toimii sosiaalisen järjestyksen puitteissa, mutta innovaatio organisoi tämän järjestyksen uudella tavalla.”

Uutta luovan aspektin sisällyttäminen sosiaalisen pääoman käsitteeseen johtaa kysymykseen, onko vapaan sivistystyön tehtävänä sekä uusintaa että uudistaa sosiaalista pääomaa (Poikela 2005). Jos puolentoistasadan vuoden sosiaalisen pääoman kasaaminen on saatu päätökseen, mistä ja miten vapaa sivistystyö ammentaa uudet innovaationsa? Ketä vapaa sivistystyö hyödyttää ja mitä hyötyä siitä on yhteiskunnalle?

\section{Vapaan sivistystyön vaikutukset ja hyöty}

Sivistystyön vaikutuksia analysoivassa tutkimuksessaan Manninen (2010) tekee erottelun aikuisopiskelun välittömien hyötyjen (esim. oppimistulokset) ja laajempien vaikutusten (esim. aktiivinen kansalaisuus, työelämävaikutukset) välillä. Tutkimuksessaan hän erittelee myös opiskeluprosessista koituvia hyötyjä opiskelijoille. Niitä ovat yhteisöön kuuluminen, sosiaalinen vuorovaikutus, itsensä toteuttaminen ja tekemisen ilo. Prosessin tuloksena puolestaan ovat välittömät hyödyt, (käytännölliset, välineelliset ja virikkeelliset hyödyt), oppiminen ja osaaminen (tiedot, taidot, näkemykset) ja rinnakkaisvaikutukset (psykologiset ja sosiaaliset hyödyt).

Ensisijainen hyödynsaaja on yksilö, mutta hyötyjen kautta syntyy seurannaisvaikutuksia (wider benefits) kuten henkistä ja fyysistä hyvinvointia, elämänsisältöä ja -laatua, työssä ja arjessa jaksamista sekä yhteiskunnallista osallistumista. Niinpä vapaa sivistystyö tuottaa "kaikkea hyvää ja aktiivisia kansalaisia”. Mannisen tutkimus sisältää vahvan arvokannanoton: muutosta tukeva oppiminen on arvokkaampaa ja hyödyllisempää kuin sopeuttava oppiminen. Sitä hän perustelee arvottavan, vertikaalisen dimension (muutostavoitteinen vs. sopeuttava oppiminen) ja vertailevan, horisontaalisen dimension (yksilö- vs. yhteisökeskeisyys) avulla.

Analyysin pulma on kuitenkin muutoksen abstraktisuus, koska käsitettä ei avata sisällöllisesti. Mitä muutos tarkoittaa, onko sillä itseisarvo oppimisen tavoitteena? Voiko muutos itsessään olla oppimisen kohde? Vastaavasti voi kysyä, mitä on sopeutuminen? Eikö sopeuttavaan oppimiseen sisälly muutos- 
ta? Miksi sopeutuminen on arvolataukseltaan negatiivinen ja muutos positiivinen määre? Manninen kyllä toteaa, että "sopeutumista ei tule nähdä yksinomaan haitallisena ilmiönä", sillä se on usein yhteiskunnassa selviytymisen ehto.

Asiallisesti hän ei puhukaan muutoksesta ja sopeutumisesta, vaan vallankäytöstä, johon liittyy valtauttava ja alistava ulottuvuus, joita hän peilaa yksilökeskeisen ja yhteisökeskeisen kasvatuksen ulottuvuuksiin. Saman tien hän tulee esittäneeksi toisenkin arvokannanoton. Nimittäin erilaiset oppimisen teoriat voidaan arvottaa sen mukaan, liittyvätkö ne positiivisesti, neutraalisesti tai negatiivisesti ladattuihin yhteisöllisen ja yksilöllisen muutoksen tai sopeuttamisen kenttiin.

Engeströmin, Freiren, bell hooksin kriittiset, kehittämishakuiset ja yhteisökasvatukselliset teoriat ja näkemykset sijoittuvat yhteisöä muuttavaan kenttään. Mezirowin transformatiivinen oppiminen sijoittuu yksilöllisen muutoksen kenttään. Sen sijaan Knowlesin andragogiikan ja ongelmalähtöisen oppimisen paikka on yksilön sopeuttamisen kentässä samoin kuin Tylerin opetusteoria ynnä yhteiskunnan tai työelämän tarpeista lähtevä koulutus on sopeuttamisen yhteisöllisessä kentässä. Ryhmittely on yritys jäsentää sosiologisesti oppimisen, kasvatuksen ja koulutuksen ilmiöitä sekä niihin liittyviä teoreettisia selitysmalleja. Puuttuu vain pisteytys enemmän ja vähemmän arvokkaiden teorioiden ja koulutusmallien välillä. Sosiaalisen pääoman näkökulmasta teorioita voisi tulkita sosiaalisina hyödykkeinä ja jopa haitakkeina.

Manninen tulee esittäneeksi kolmannenkin arvokannanoton joskin hieman erikoisella tavalla:” sosiaalisen pääoman ja aktiivisen kansalaisuuden lisääntyminen voidaan nähdä myös sopeuttavina ilmiöinä, sillä etenkin Putnamin (2005) määritelmän mukaan sosiaalinen pääoma on yhteiskuntarauhaa turvaava ilmiö.” Sosiaalinen pääoma on siis jo lähtökohtaisesti kielteinen, sopeuttava ja kontrolloiva ilmiö, koska se turvaa yhteiskuntarauhaa. Siten vapaa sivistystyö olisi pikemminkin haitake kuin hyödyke, koska se ei näyttäisi tuottavan yhteiskunnallista muutosta.

Aikuiskasvatuksen ja vapaan sivistystyön tulisi näkyä "muutoksen ideologiana", jonka etujoukkona "tutkijat ja alan kehittäjät käyvät muutoskeskustelua ja siirtävät sitä yliopistojen kurssikirjavalintojen kautta myös tuleville ammattilaisille" (Manninen 2010). Kaukana ei ole vallankumousromanttinen näkemys, jossa aikuiskasvatukselle ja vapaalle sivistystyölle on varattu pelkästään vapauttajan rooli. Siitä seuraa, että tärkein hyöty olisi poliittinen ja muut hyödyt ovat siihen verrattuna toisarvoisia. Perimmäinen kysymys jää auki - mikä olisi muutoksen sisältö? Ehkä sisältöä ei enää ole?

\section{VALISTUKSEN LOPPU JA VAPAAN SIVISTYSTYÖN TULEVAISUUS}

1990-luvun taitteessa Fukuyama (1989) esitti kuuluisat teesinsä historian lopusta. Niillä hän tarkoitti länsimaisen demokratian ja hyvinvoinnin saavuttaneen huippunsa. Sivilisaatio ja sivistys olivat tavoittaneet lakipisteensä. Vuosikymmenen lopulla myös Delanty (1998) esitti teesinsä tiedon lopusta, mikä tarkoitti itseisarvoisen tiedon ja akateemisen tieteen kulta-ajan loppua. Tieteenteko ja tiedon tuottaminen ei ole enää yliopistojen yksinoikeus, koska kuka tahansa ja mikä tahansa organisaatio kykenee samaan, mikäli se varustetaan riittävillä resursseilla. Globaalin historian ja akateemisen tieteen näyttämöllä valistuksen suuri kertomus näytti saavuttaneen päätepisteensä.

Suomessa samaan kertomukseen, mutta pienempään mittakaavaan liittyen Juha Sihvonen (1990) esitti kysymyksen "onko vapaat sivistystyöt tehty?" Vastaus siihen on yhä avoin, mutta kysymys on jakanut sivistystyöntekijöitä eri leireihin. Osa katsoo taaksepäin ja hakee vastausta kansakunnan, kansanvalistuksen, kansallisten liikkeiden, kansalaiskasvatuksen ja yhteisöllisyyden ideaaleista. Heitä näyttää yhdistävän nostalgia ja romantiikka riippumatta siitä, onko kyse kansallisvaltion luomisesta tai työväen vallankumouksesta. Toinen osa katsoo eteenpäin ja on vauhdilla mukana informaatioyhteiskunnan globaaliverkostoissa, digitaaliajan teknologian hyödyntämisessä ja virtuaalisyhteisöissä sekä rakentaa näköiskuvaansa facebookin, twitterin ja blogien näyttämöillä tai muualla sosiaalisessa mediassa. Vapaalle sivistystyölle koittaa uusi aika, eivätkä he ole väärässä.

Jos edellisille on tärkeä katsoa historiaan ja jopa unohtua sinne, niin jälkimmäisillä on kiire tule- 
vaisuuteen jopa nykyhetken unohtaen. Historiaa voi kuitenkin tulkita kummastakin näkökulmasta ja ymmärtää sitä kautta nykyisyyttä. Jokinen ym. $(2012,4)$ avaavatkin raportissaan yhdistävän näkökulman kysymällä:

"Miten vapaan sivistystyön hyödyllisyyttä on perusteltu historian eri vaiheissa ja miten sivistyshyöty ilmenee 2010-luvulla sekä miten oppilaitoksissa tulkitaan sosiaalisen pääoman käsitettä?"

Kysymys implikoi lisäkysymyksen: voiko sivistyshyödyn osoittaa ja jos voi, miten sitä voisi mitata? Jos ja kun veronmaksajat ja valtio esittävät kysymyksen sivistystyön hyödyllisyydestä, hyöty on myös pystyttävä osoittamaan. Itseisarvoista sivistystä ei ole, kuten ei myöskään ole itseisarvoista sivistystyötä. Arvo on ansaittava tekemällä hyödyllisiä ja sivistäviä asioita.

\section{Sivistäminen hyvinvoinnin, demokratian ja yhteiskuntarauhan rakentamisena}

Valtio- ja sivistysfilosofina Snellman näki "siveellisyyden ja lainkuuliaisuuden" yhteiskunnan kivijalkana, joka perustui kielen, kulttuurin ja tapojen yhtenäistämiseen. Siveellisyys tarkoitti kokonaisuutta, kulttuuria ja "siveellistä tilaa”, johon kuuluivat väestön tarpeiden tunnustaminen, perheiden hyvinvointi, inhimilliset tarpeet tunnistava kansalaisyhteiskunta ja valtio isänmaallisen sivistyksen korkeimpana ihanteena. Lainkuuliaisuus oli kansalaisyhteiskuntaa koossa pitävä voima ja sen jäsenenä itsetietoisuuteen pyrkivät ihmiset edistivät kansakunnan yhteistä asiaa.

Aineellinen ja henkinen hyvinvointi tukivat toisiaan, ja yhteiskunnan epäkohdat oli ratkaistava. Mitään itseisarvoista Snellmanin sivistyskäsityksessä ei ollut. On helppo todeta hänen toimineen kansakunnallisen sosiaalisen pääoman luomisen puolesta. Sivistymisen vaikutukset ja hyöty koituivat viimekädessä valtioperustusten vahvistamisen hyväksi. Tavoitteena ei ollut enempää eikä vähempää kuin yhtenäinen kansakunta ja kulttuuri. Samaan tavoitteeseen tähtäsi myös Grundtvigin kansanopistojen perustamiseen johtanut ajatus "talonpojan herättämisestä" yhteiskunnalliseen tietoisuuteen ja toimintaan.

Kansanopistoaate yhdisti aineelliseen hyvään pyrkimisen ja isänmaallisuuden tavalla, joka johti in- ternaattimuotoisten kansanopistojen perustamiseen maaseuduille. Samaan virtaan yhdistyi Yrjö-Koskisen fennomania ja "älyn ja kekseliäisyyden korostaminen” elinkeinojen tueksi. Myös Castrén antoi sivistyspanoksensa uusiin teollisiin elinkeinoihin liittyen. Kaupunkien työväestö tarvitsi oman sivistysahjonsa, minkä perusteella ryhdyttiin rakentamaan koko maan vähitellen kattanutta työväen- ja kansalaisopistojen verkostoa. (Jokinen ym. 2012.)

1800- ja 1900-lukujen vaihteen molemmin puolin kansalliset liikkeet ja kansainvälinen työväenliike olivat yleismaailmallisesti törmäyskurssilla. Suomessa kieli-, kulttuuri-, raittius- sekä sosiaaliset ja poliittiset kysymykset tarvitsivat ratkaisuja. Kansansivistysliike sisälsi myös itsessään eri aate- ja uskontosuuntia. Kansallisen ja kansainvälisen kuohunnan tuloksena syntyi itsenäinen valtio, mutta ei yhtenäinen kansakunta. Kansalaissota osoitti, miten pahasti yhteiskuntarauhan ja eri väestönosien välisen luottamuksen rakentamisessa oli epäonnistuttu.

Sodan jälkeen sosiaalisen pääoman kokoaminen oli aloitettava alusta ja uudelta pohjalta. Voittajien pystyttämä valtiovalta oli saatava tukemaan kansansivistystyötä, mikä ei tarkoittanut ainoastaan opinnollista sivistymistä vaan ennen muuta yhteiskunnallisten olojen tasoittamista, kansalaisyhteiskunnan rakentamista ja elinolojen kohentamista.

Maailmansotien välillä Suomi oli niitä harvoja eurooppalaisia valtioita, joissa kyettiin patoamaan väkivaltainen poliittinen liikehdintä ja pitämään kiinni demokraattisen oikeusvaltion periaatteista. Kehityksen symbolisena huipentumana voidaan pitää sotavuosien aikana solmittua "tammikuun kihlausta", jossa työnantaja- ja työntekijäjärjestöt saivat aikaan valtakunnallisesti kattavan työmarkkinasopimuksen 1940. Sopimusta voi pitää myös puoli vuosisataa kestäneen konsensus-Suomen rakentamisen alkuna.

Kansallisen luottamuksen ja yhteiskuntarauhan rakennustyössä vapaalla sivistystyöllä oli eittämättä tehtävä, jota haluttiin tukea julkisin varoin vuodesta toiseen.

\section{Yhteisöpohjaisesta kansansivistämisestä yksilölliseen sivistystyöhön}

Castrénin "elannon kirkastaminen" oli hyvin maan- 
läheinen ilmaus kansansivistystyön hyödystä. Hänen aikanaan vapaa sivistystyö alkoi saada institutionaalisenmuotonsa. Erityisesti työväenopistot ja kaupunkien työväki olivat castrenilaisen sivistystyön keskiössä. Castrénille sivistämisen yhteys aineellisten elinolojen kohentamiseen oli selviö. Sivistyminen tarjosi kanavan sosiaaliseen nousuun ja vaikutti siihen, että radikaalit ideologiat eivät helposti vallanneet työtätekevien mieliä.

Sivistymisen hyödyt näkyivät opinnollisen sivistyksen laajentumisena, luku- ja kirjoitustaitoisten määrän lisääntymisenä sekä koulutus- ja elintason kohoamisena. Siten luotiin sivistyksellistä infrastruktuuria teollistuvan yhteiskunnan ja tulevan sosiaalisen hyvinvoinnin rakentamista varten. Vapaan kansanvalistus- ja -sivistystyön hyödyt olivat välittömiä yksilöiden hankkimien tietojen ja taitojen merkityksessä. Aikuisenakin hankitusta luku-, kirjoitus- ja laskentotaidosta oli hyötyä työelämässä, joka tarvitsi osaavaa ja kurinalaisesti käyttäytyvää työvoimaa. Castrénille yhteiskuntarauha oli keskeinen tavoite ja sitä toteuttamaan tarvittiin hyvä ihminen ja kunnon kansalainen, joka osasi toimia sivistyneesti omassa elinpiirissään ja demokraattisessa yhteiskunnassa. (Jokinen ym. 2012.)

Kansansivistystyöstä kehkeytyi vähitellen oppiaine nimeltä kansansivistysoppi ja lopulta yliopistollinen aikuiskasvatustiede. Opillista ja tieteellistä sisältöä ja tehtävää määrittelivät 1900-luvun puolivälin jälkeen professorit Urpo Harva ja Aulis Alanen. Jo Castrén oli nostanut yksilön sivistämisen etualalle yhteisöllisten arvojen jäädessä taustavaikuttajiksi. Sivistämisen, kasvatuksen ja koulutuksen kohteena nähtiin keskivertokansalaiseksi abstrahoitu yksilö, jokamies ja -nainen, jonka periaatteessa saattoi kohdata missä ja milloin tahansa.

Harva (1955) kiteytti yksilön kehittymistarpeen "kasvamaan saattamisen" ajatukseen. Saattajaa tarvittiin tukemaan yksilöä matkalla sivistykseen, demokraattisen yhteiskunnan jäsenyyteen ja aktiiviseen kansalaistoimintaan. Harvalle sivistyneen yhteiskunnan rajaus oli selkeä. Aikuiskasvattajan tai sivistystyöntekijän ei ollut mielekästä kiinnostua työelämästä, ammatillisesta opiskelusta tai tuotannollisista pyrkimyksistä. Tässä mielessä sivistys oli sivistyneen yksilön "klubihyödyke" (Bouerdieu 1986), joka auttoi erottautumaan tavanomaisuudesta sekä tuki sosiaalista nousua ja kiinnittymistä kulttuurisiin ja yhteiskunnallisiin harrastuksiin. Sivistys antoi statuksen.

Alasen (1985) käsitteistössä hyvä ihminen ja kunnon kansalainen muuttui kokonaispersoonaksi, joka halusi kehittyä, ei vain yleissivistymisen merkityksessä vaan myös oppia erilaisia tietoja ja taitoja, joita tarvittiin työssä ja ammatillisessa elämässä. Lisäksi koko persoonallisuuden kehittämisessä tuli huomioida emotionaalinen ja moraalinen kehittyminen. Sivistynyt persoonallisuus kehitti kokonaisvaltaisesti itseään, ja tähän kehittämiseen tarvittiin aikuiskasvatuksen ja -koulutuksen kokonaisvaltaista tukijärjestelmää.

Kaiken kattavan aikuiskasvatusjärjestelmän ja ehjän kokonaispersoonallisuuden kehittämisen välillä vallitsi holografinen suhde, jossa ratkaisevin ero oli vain erilainen mittakaava systeemin makro- ja mikrotasolla. Sivistystyön ja aikuiskoulutuksen tärkeimmäksi mittariksi nousivat suuret osallistumisluvut, jotka päällekkäisesti yhteenlaskettuina olivat jopa enemmän kuin koko aikuisväestö. Vapaa sivistystyö voi hyvin valtion ja kuntien sitoutuessa sen laajenevaan ylläpitämiseen. Suuria osallistujalukuja korostavan järjestelmän rakentaminen oli alkanut 1970-luvun alun Aikuiskoulutuskomitean mietinnöstä, jonka kirjoittaja Alanen oli. Sen jälkeen eri teemoihin liittyviä komiteamietintöjä tehtiin tasaista tahtia aina 1990-luvulle saakka.

\section{Koulutus- ja sivistysmarkkinoiden luominen}

1980-luvulla saavutettu kansallinen konsensus ja kansalaiskasvatuksen ideaali alkoi menettää sosiaalisen käyttövoimansa. Järjestelmäkeskeinen ajattelu liudentui vähitellen ja suora valtionapu korvattiin laskennallisilla suoritteilla. Rahoitukselle haettiin kattoa ja järjestelmän toimijoiden keskinäinen kilpailuttaminen oli siihen keino. 1990-luvulta lähtien vapaan sivistystyön trendi on ollut laskeva ja volyymi on vähentynyt. Valtiokeskeisen ideologian tilalle astui markkinatalous ja individualismi. Haluttiin edistää yksityistettyjä toimintamuotoja ja oman elämänsä sankarien henkilökohtaisia tavoitteita.

Aikuiskoulutuspolitiikassa tehtiin uusia käsite- 
määrityksiä. Omaehtoinen aikuisopiskelu, henkilöstökoulutus ja työvoimapoliittinen aikuiskoulutus määrittivät vastedes aikuiskasvatuksellisia tarpeita. Esimerkiksi kansanopistot olivat "omaehtoisen tehtävänhaun" tilanteessa, jolloin ne "joutuivat" ottamaan ohjelmiinsa ammatillisia, lähinnä sosiaali- ja koulutusalan opintoja. Esiin nousi ääniä, joiden mukaan kilpailuttaminen ja uusi julkishallinto uhkasivat tehdä tyhäksi koko yhteiskunnallisen sivistystyön. Aikuiskasvatusta ei enää määritelty yhteiskunnallisen sivistystyön lähtökohdista. Vapaa sivistystyö näytti ajautuvan omaehtoisten opintojen marginaalin.

Puolentoista vuosisadan ajan kasattu yhteiskunnallinen luottamus ja sosiaalinen pääoma alkoi osoittaa rapautumisen merkkejä (Putnam 2000). Vapaan sivistystyön kyvykkyys tuottaa sivistyshyötyä asetettiin yhä selkeämmin kyseenalaiseksi. Alkoi näyttää siltä, että vapaat sivistystyöt on todella tehty. Uhattuna ei ole ollut vain sivistystyö vaan koko hyvinvointiyhteiskunta. Oli aika asettaa kysymys uuden ajan sivistystehtävästä, vapaan sivistystyön tuottamasta hyödystä ja kyvystä rakentaa uutta sosiaalista pääomaa.

\section{Haasteena sivistysosaaminen}

Vanhastaan vapaaseen kansansivistystyöhön on kuulunut ajatus, että tieto, tietoisuus ja sydämen sivistys tekevät sivistyneen ihmisen. Teollisen ajan kansalaisen piti hallita perustiedot ja -taidot, mutta myös osata suhtautua muihin ja toimia sivistyneellä tavalla. Nyky-yhteiskunnassa hänen pitäisi olla omaaloitteinen, kyseenalaistava, yritteliäs ja yhteistyökykyinen tiimityöntekijä. Tietämisen arvo on laskenut, koska tieto on helposti kenen tahansa saatavilla. Sen sijaan tietoisuuden ja osaamisen rooli, ei vain tiedon ja taidon vaan moraalisen ja eettisen osaamisen merkityksessä, on kasvanut ikään kuin toiseen potenssiin verrattuna teollisen ajan tarpeisiin.

Kysymykset oikeudenmukaisuudesta, tasa-arvoisuudesta, yhteisyydestä ja ympäristöistä, kuluttamisesta ja kestävästä kehityksestä sekä monet muut ihmiskuntaa ja yhteisöjä koskevat haasteet eivät sinänsä ole uusi asia. Ne ovat kuitenkin aktuaalisempia kuin koskaan ja siksi ne ovat sivistyksen keskeisiä arvoja ja tavoitteita. Sivistysosaaminen tarkoittaa ennen muuta kykyä ajatella, toimia ja ratkoa yhteiskunnallisia ongelmia kestävällä ja oikeudenmukaisella tavalla. Käytännössä se tarkoittaa aktiivista kansalaisuutta ja yhteisöllistä toimintaa, yksilöllistä kyvykkyyttä ja toisten arvojen kunnioittamista sekä kykyä vuorovaikutukseen ja kulttuurien kohtaamiseen.

Moni sivistystyön asiantuntijana itseään pitävä vierastaa sanaa osaaminen, koska se tuo mieleen työmarkkinoiden mantraksi muodostuneen osaamisvaatimuksen. Osaaminen ei kuitenkaan tarkoita asian teknistä hallintaa tai pelkästään käytännön taitoa. Myös tärkeimmät työelämän pätevyydet ovat luonteeltaan yleissivistäviä. Jatkuvan oppimisen, vuorovaikutuksen, yhteistyön, ongelmanratkaisun ja ajattelun taidot ovat esimerkkejä pätevyyksistä, jotka toimivat yhtälailla arjen, kulttuurin ja sosiaalisen kuin työelämänkin yhteyksissä.

Ammatti- ja yleissivistyksen välille ei enää voida asettaa edes veteen piirrettyä viivaa. Esimerkiksi sivistynyt johtaminen tuotantoelämässä on yhtä olennaista kuin sivistynyt johtaminen kulttuuri-instituutiossa tai vapaan sivistystyön oppilaitoksessa. Sivistysosaamisen puute sen sijaan on johtanut tilanteeseen, jossa johtava eliitti toimii epäeettisesti kahmien toiminnan hyödyt itselleen ja siirtäen kustannukset muiden kannettavaksi.

\section{SIVISTYSHYÖDYN OSOITTAMINEN - SUORITTEISTA INDIKAATTOREIHIN}

Hyödyn mittaamisen ensimmäinen pulma on siinä, että mitataan sitä, mitä on helpointa mitata: tunteja, päiviä, vuosia, suorituksia, ylipäätään suoritteita ja määrää. Mittaamisesta tulee helposti itsetarkoitus, sillä jollakin keinoilla on osoitettava kohteen erilaisuus, eritasoisuus ja eriarvoisuus resurssien kohdentamisen helpottamiseksi. Helpoin ratkaisu on kilpailutus. Mittaamisen aikajänne on ongelmista vakavin, sillä pelkkä tulosmittaaminen johtaa seurauksiin, joista vain osa on haluttuja, osa arvaamattomia ja osa negatiivisia, jopa katastrofaalisia.

Jokisen ym. (2012) tutkimus osoittaa, että vapaan sivistystyön järjestäjillä ei ole suorite- ja tulosmittaamisesta kovin hyviä kokemuksia. Sivistyshyötyä ei myöskään haluta "mitata", koska sen uskotaan olevan mahdotonta tai koska mittaaminen loukkaa it- 
seisarvoisen sivistyksen edistämistä. Järjestäjät ovat pitkälle oikeassa. Mittareiden kehittelijät sortuvat juuri siihen, mikä on mittaamisessa helpointa, siis suoritteisiin ja määrällisiin tuloksiin. Sitä kautta mittaamisesta tulee itsetarkoitus. Mitataan, jotta saadaan vertailulukuja, joilla järjestäjiä voidaan kilpailuttaa ja asettaa paremmuusjärjestykseen. Siitä taas seuraa, että mittaamatta jäävät juuri ne tekijät, joilla pitkän aikavälin vaikutukset tuotetaan.

Vaikka tutkimus oli rajallinen otanta ${ }^{3}$, siitä voidaan vetää johtopäätös, jonka mukaan vapaan sivistystyön oppilaitoksilla on varsin vähäinen valmius vastata uuden vuosituhannen kehitystarpeisiin (mt., 79). Sivistystehtävän koetaan pysyneen ennallaan, painotukset ovat aktiivin kansalaisuuden edistämisessä ja yksilön persoonallisen kasvun tukemisessa. Oppimiseen, sosiaalisuuteen ja elämänlaatuun liittyvät tärkeimmät sivistyshyödyt kyetään kyllä tunnistamaan ja vapaan sivistystyön toimijat uskovat, että heidän tehtävänään on yhteisöllisyyden edistäminen. Käytännössä kyse on kuitenkin enemmän opintoryhmä- tai kurssiyhteisöllisyyden edistämisestä kuin tavoitetietoisesta sosiaalisen pääoman rakentamisesta.

Hyötyjen uskotaan koituvan yhteiskunnalle pitkän aikavälin vaikutuksina. Sen sijaan niiden mittaamista ei pidetä mahdollisena. On vain luotettava siihen, että vapaasta sivistystyöstä on hyötyä, koska se on hidas ja aikaa vievä prosessi. Sivistyshyödyn mittaamisessa ei kuitenkaan ole kyse siitä, mitataanko vai eikö mitata, vaan mitataan joka tapauksessa. Kyse on enemmän siitä, mitä mitataan ja miten mitataan. Jos mittaamisen perusteisiin ja tapoihin ei haluta vaikuttaa, niiden perustelut ja kehittely jää vapaan sivistystyön ulkopuolisten toimijoiden määriteltäviksi eli lähinnä niille, joiden tehtävänä on kohdentaa resursseja sivistystyöhön.

Tärkeintä on huomata, että tulokset syntyvät lyhyellä ja vaikutukset pitkällä aikavälillä. On oltava samaan aikaan sekä ketterä että pitkäjänteinen. Tiedetään, että tulos ja sen laatu on seurausta toimintaprosessista, jossa kaikki pitää olla kohdallaan, jos halutaan korkeaa laatua. Kun tulosvaatimus esitetään ulkoapäin ja määrällisenä vieläpä ilman käsitystä siitä prosessista, joka sen perustana on, seurauksena on kaiken huomi- on keskittäminen määrään ja nopeaan tuotantoon. Ja kun sen seurauksena laatutaso alkaa laskea, seuraa peittelyä, mikä taas lisää kontrollin tarvetta.

Esimerkiksi sivistyshyötyä tuottavan pedagogisen prosessin laatu voi jäädä kokonaan huomiotta määrällisiin tuloksiin keskittymisen takia. Pedagogisen laadun lisäksi pitkävaikutteista sivistyshyötyä voitaisiin arvioida indikaattoreilla, joilla osoitetaan esimerkiksi kyvykkyyttä tehdä yhteistyötä paikallisten, alueellisten ja aina kansainvälisten toimijoiden kanssa. Yhteistyössä onnistumisen seuranta voisi kohdistua sosiaalisen ja kulttuurisen mutta myös fyysisen ja psyykkisen hyvinvoinnin tuottamiseen, jota tehdään esimerkiksi yhdyskuntatyön toimijoiden, sosiaali-, terveys- ja kulttuurialan ammattilaisten kanssa.

Sisällöllisen profiloitumisen ja erikoistumisen merkityksessä yhteistyö voisi olla myös maakunnan ja valtakunnan rajat ylittävää esimerkiksi vastattaessa maahanmuuton, eri kulttuurien, etnisten ryhmien kohtaamisen ja verkostoitumisen tarpeisiin. Hyvinvoinnin ja sivistystyöhön osallistumisen välillä voidaan olettaa vallitsevan positiivisen riippuvuuden. Sitä osoittavien ja muiden sivistysindikaattorien avulla estettäisiin myös käpertymistä omahyväisen institutionaalisen erinomaisuuden todisteluun.

\section{JOHTOPÄÄTÖS}

Jokisen ym. (2012,91-97) raportti osoittaa, että monilla vaikutusmittareilla on jo alkumuotonsa muun muassa maahanmuuttoon, kielitaitoon, tietoyhteiskunta- ja jatko-opintovalmiuksiin, terveyden edistämiseen ja syrjäytymisen vähentämiseen liittyen. Indikaattorien kehittely samoin kuin vaikutusten arviointi niiden avulla edellyttää aktiivista ja jatkuvaa tutkimustoimintaa. Valitettavasti Suomessa ei ole enää yhtäkään yliopistollista tutkimus- ja opetuslaitosta ${ }^{4}$, jossa ensisijaisesti keskityttäisiin aikuiskasvatuksen ja vapaan sivistystyön keskeisimpään problematiikkaan. Tutkimista vaativa seuranta tai pelkästään jo olemassa olevien tilastotietojen päivittäminen ja hyödyntäminen jää satunnaiseksi.

Huono laatu on kulutusyhteiskunnan ominaisuus, sillä tuotteiden elinkaarta halutaan jopa tietoisesti lyhentää muun muassa kestokulutushyödykkeiden kohdalla. Toisaalta konkreettisten kulutushyö- 
dykkeiden kohdalla huono laatu on helppo huomata, kun taas sivistystyön laatua, hyötyjä tai vaikutuksia on vaikea havaita tai osoittaa. Markkinaperustainen laatukriteeri ei toimi, koska asiakas ei maksa subventoidusta tuotteesta täyttä hintaa. Vetoaminen menestykselliseen historiaan ei sekään riitä, koska ympäröivät olosuhteet ovat muuttuneet. Ainoa tapa osoittaa sivistystyön hyöty liittyy oman kyvykkyyden ja toiminnan vaikutusten osoittamiseen ymmärrettävällä ja riittävän konkreettisella tavalla.

Vapaan sivistystyön sisäiset prosessit, suoritteet ja tulokset ovat tekijöitä, joissa vertailukohtana tulisi olla aikaisempi toiminta ja vasta toissijaisesti lähinnä kehittämiseen liittyvä vertailu muihin. Oppilaitosten olisi itse vastattava prosessiensa tehokkuudesta ja laadusta, kuten myös tulostensa määrästä ja laadusta, jolloin kyse on autonomiasta ja kyvystä toimia joustavasti ja ketterästi muuttuvissa olosuhteissa. Sen sijaan yhteiskunnalliseen tilivelvollisuuteen liittyvän sivistystyön laadun ja pitkän aikavälin vaikutusten osoittaminen tarvitsee indikaattoreita, joilla yksilön, yhteisöjen ja viimekädessä yhteiskunnan saamat hyödyt voidaan todentaa, puhuttiinpa sitten sivistys-, kulttuuri- tai sosiaalisen pääoman luomisesta.

Monet vapaan sivistystyön toimijat näkivät, mihin 1990-luvun alkupuolen lama sekä sosiaali-, koulutus- ja kulttuuripolitiikan mahdollisuuksien kaventaminen johtavat. Kaksikymmentä vuotta on sopiva perspektiivi katsoa myös eteenpäin. Mitä vapaa sivistystyö voi tehdä aiheutuneiden vaurioiden korjaamiseksi, syrjäytyvien sukupolvien ketjun katkaisemiseksi ja uusien mahdollisuuksien luomiseksi? Miten 21. vuosisadan sivistysosaaminen voi tukea moraalisesti, eettisesti, taloudellisesti ja ekologisesti kestävän kansainvälisen yhteiskunnan, alueellisten ja paikallisten kulttuurien kehittymistä?

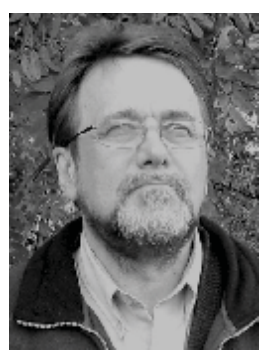

Esa Poikela

kasvatustieteen professori

Lapin yliopisto
1. Terveydenhuolto on tunnetusti yhteiskunnalle kallis investointi- ja ylläpitojärjestelmä, joka pitää kyetä perustelemaan hyvin ja järjestämään optimaalisella tavalla. Siihen tarvitaan uudenlaista laatukustannusajattelua ja kansantaloudellisia mittareita, joilla hyödyt ja -vaikutukset pystytään osoittamaan. Niin asiakkaat kuin veronmaksajatkin on vakuutettava palvelun hyödyllisyydestä. (Porter 2008.)

2. Oikeuskäytäntöön on kehitetty restoratiivisen oikeuden lähestymistapa, joka tulee yhteiskunnalle huomattavan paljon halvemmaksi kuin kaikkien rikkeiden ja riitojen vieminen oikeuskäsittelyyn. Perusajatuksena on, että fasilitatiivisen sovittelun johdolla ristiriidan osapuolet ratkaisevat riitansa itse. Kun konfliktin osalliset kykenevät sopimaan riitansa, yksilöt ja yhteiskunta hyötyvät. Syntyy luottamusta ja sosiaalista pääomaa. (Brunila 2010.)
3. Tutkimuksessa oli mukana 5 kansalaisopistoa, 4 kansanopistoa ja 5 opintokeskusta, jotka valittiin harkittua otantaa noudattaen vapaan sivistystyön oppilaitoksista. Otannan kriteerejä olivat maahanmuuttajien koulutus, toiminta-alueen rakennemuutos sekä yhteiskunnallisen orientaation ja alueellisen sijainnin edustavuus.

4. Pieninä yksiköinä aikuiskasvatuksen laitokset on sulautettu opettajakoulutuksen hallitsemiin tiedekuntiin. Seurauksena on ollut tutkimuksen, opetuksen ja tiedepohjaisen kehittämisen hajautuminen eri yliopistoihin. Samalla myös resurssit ovat pirstoutuneet eikä niin sanottua kriittistä massaa kyetä tavoittamaan kauttaaltaan korkeatasoisen tutkimuksen saavuttamiseksi. 


\section{LÄHTEET}

Alanen, A. 1985. Johdatus aikuiskasvatukseen. Radion aikuiskasvatussarjan ensimmäinen osa. Oy Yleisradio Ab.

Bourdieu, P. 1986. The Forms of Capital. In J.G. Richardson (ed.) Handbook of Theory and Research for the Sogiology of Education. New York: Greenwood Press, 241-258.

Brunila, T. 2010. Sovittelu tie tulevaisuuteen. Teoksessa E. Poikela (toim.) Sovittelu - ristiriitojen kohtaamisesta konfliktin hallintaan. Jyväskylä: PSKustannus Oy, 23-43.

Coleman, J.S. 1988. Social Capital in the Creation of Human Capital. American Journal of Sociology 94, 95-120.

Delanty, G. 1998. The idea of the university in the global era: from knowledge as an end to the end of Knowledge. Social Epistemology. 12: 1. 3-25.

Fukuyama, F. 1989. The End of History. The National Interest. Summer 1989.

Harva, U. 1955. Aikuiskasvatus. Johdatus aikuiskasvatuksen teoriaan ja työmuotoihin Suomessa. Helsinki: Otava.

Jokinen, J., Poikela, E. \& Sihvonen, J. 2012. Sivistyshyöty ja sosiaalinen pääoma vapaassa sivistystyössä. Vapaan Sivistystyön Yhteisjärjestö. Turku: Suomen yliopistopaino Uniprint.

Manninen, J. 2010. Sopeuttavaa sivistystyötä? Aikuiskasvatus. 30 (3), 164-174.

Poikela, E. 2005. Onko sosiaalisen pääoman värillä väliä? Teoksessa E. Poikela (toim.) Oppiminen ja sosiaalinen pääoma. Tampere: Tampere University Press, $11-27$.

Porter, M. 2008. Luento Finlandia talossa, järjestäjänä Sitra. J. Alkio( toim.) Terveydenhuollolla on väärät tavoitteet. Helsingin Sanomat 3.10.2008.

Putnam, R.D. 2000. Bowling Alone. The Gollapse and Revival of American Community. New York: Simon \& Schuster.

Ruuskanen, P. 2001. Sosiaalinen pääoma - käsitteet, suuntaukset ja mekanismit. Valtion taloudellinen tutkimuskeskus. Helsinki: VATT-tutkimuksia 81. Oy Nord Print Ab.

Sihvonen, J. 1990. Onko vapaat sivistystyöt tehty? Opistotoiminnan kriittisiä kysymyksiä. Kansalais-ja työväenopistojen liitto KTOL r.y. Helsinki: Kowapaino Oy.

Tuomi, I. 2004. Sosiaalinen Innovaatio. Kolumni. Tekniikka \& talous 15.4.2004. 